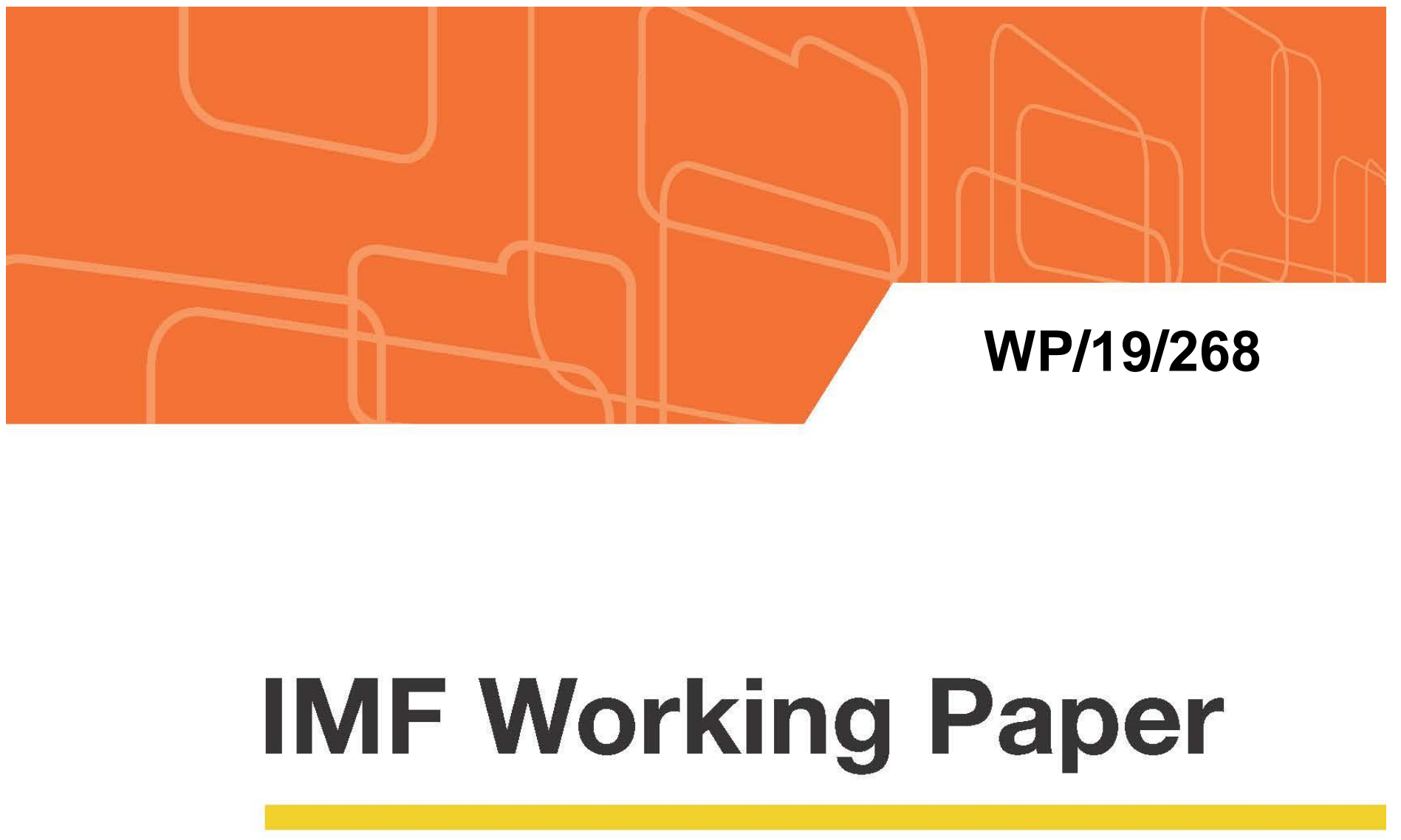

\title{
How Do Changing U.S. Interest Rates Affect Banks in the Gulf Cooperation Council (GCC) Countries?
}

by Olumuyiwa S. Adedeji, Yacoub Alatrash, and Divya Kirti

IMF Working Papers describe research in progress by the author(s) and are published to elicit comments and to encourage debate. The views expressed in IMF Working Papers are those of the author(s) and do not necessarily represent the views of the IMF, its Executive Board, or IMF management. 


\title{
IMF Working Paper
}

Middle East and Central Asia Department (MCD)

\section{How Do Changing U.S. Interest Rates Affect Banks in the Gulf Cooperation Council (GCC) Countries?}

\author{
Prepared by Olumuyiwa Adedeji, Yacoub Alatrash, and Divya Kirti* \\ Authorized for distribution by Tim Callen
}

December 2019

\section{IMF Working Papers describe research in progress by the author(s) and are published to} elicit comments and to encourage debate. The views expressed in IMF Working Papers are those of the author(s) and do not necessarily represent the views of the IMF, its Executive Board, or IMF management.

\begin{abstract}
Given their pegged exchange rate regimes, Gulf Cooperation Council (GCC) countries usually adjust their policy rates to match shifting U.S. monetary policy. This raises the important question of how changes in U.S. monetary policy affect banks in the GCC. We use bank-level panel data, exploiting variation across banks within countries, to isolate the impact of changing U.S. interest rates on GCC banks funding costs, asset rates, and profitability. We find stronger pass-through from U.S. monetary policy to liability rates than to asset rates and bank profitability, largely reflecting funding structures. In addition, we explore the role of shifts in the quantity of bank liabilities as policy rates change and the role of large banks with relatively stable funding costs to explain these findings.

JEL Classification Numbers: G21, E43

Keywords: Banks, Gulf Corporation, U.S. Monetary Policy, Competition Authors’ E-Mail Addresses: oadedeji@imf.org; alatrash@uw.edu; $\underline{\text { dkirti@imf.org }}$
\end{abstract}

\footnotetext{
*We are grateful to Aidyn Bibolov, Tim Callen, Tokhir Mirzoev, and seminar participants at the IMF for helpful suggestions.
} 


\section{INTRODUCTION}

Monetary policy in the Gulf Cooperation Council (GCC) countries is conducted in the context of fixed exchange rate regimes and the open capital accounts. ${ }^{2}$ National currencies are pegged to the U.S. dollar - or in the case of Kuwait, to an undisclosed basket of currencies tilted towards the U.S. dollar. The pegs are maintained by managing the magnitude of short-term interest rate differentials with U.S interest rates. Policy rates in GCC countries have generally mirrored recent shifts in U.S. monetary policy. This raises the important question of how changing policy interest rates impact the GCC banking sector.

Previous work on the impact of U.S. interest rates on GCC economies largely focuses on aggregate data (Sheehan and Russer (1995), Espinoza and Prasad (2012), Alghaith and others (2014), and Adedeji and others (2019)). To address the challenges the literature faces in isolating the impact of interest rates from coincident macroeconomic shocks, this paper offers two methodological contributions. First, we construct asset and liability rates for GCC countries, given that interest rate series are not available for some of these countries. Implied deposit and lending rates are constructed at the GCC, country, and bank levels. Second, we use bank-level panel data to explore variation across banks within countries to isolate the impact of changing U.S. interest rates on GCC banks' funding costs and profitability and derive monetary policy implications.

We study the effect of changes in U.S. monetary policy on the cost of funding, lending rates, and profitability of GCC banks. We are not aware of prior work on GCC countries that studies these links by looking at variation across banks within country. Our approach aims to isolate the impact of interest rates in a manner that is difficult to do with aggregate data. We build on Drechsler and others (2017) and Kirti (2017), who study cross-sectional differences in U.S. banks' interest rate exposure. This literature finds considerable variation across banks in the U.S. in their interest rate exposure. We find similar heterogeneity across banks in the GCC and exploit this variation in the cross-section. These authors also find that U.S. banks adjust the interest rate exposure of their assets to match that of their liabilities. In this paper, we explore if this is the case for banks in the GCC.

We also examine the role of competition in determining interest rate pass-through, with implications for the transmission of monetary policy. With stronger competition, margins are compressed, implying that loan and deposit rates move closely with market and policy interest rates. Indeed, van Leuvensteijn and others (2013) find that competition is an important determinant of interest rate pass-through across Euro area countries.

GCC policy rates and bank liability rates largely follow U.S. policy rates, both in aggregate and at the country level. There are, however, substantial differences across individual GCC banks in the extent to which their liability interest rates are sensitive to shifting monetary policy in the U.S. We suggest that this is an important dimension of cross-sectional variation that may help study the impact of U.S. monetary policy on GCC banks.

\footnotetext{
${ }^{2}$ See IMF (2019) for a discussion of the benefits and costs of pegged exchange rates given the current structures of these economies.
} 
We find liability rates to be more sensitive to changes in U.S. monetary policy than asset rates and profitability. Following tighter U.S. monetary policy, more liability-sensitive GCC banks see their liability interest rates rise. These rate increases attract larger quantities of funding, limiting scope for these banks to raise asset rates. Competition is relevant as well: large banks can have an outsized effect on markets in concentrated banking systems. The presence of large banks with more stable funding costs also constrains liability sensitive banks' ability to raise asset rates. This places pressure on profitability for liability sensitive banks (our regressions show a negative, but statistically insignificant, impact on profitability).

Stronger pass-through to liabilities than to assets is consistent with stronger competition in deposit and funding markets than in loan markets. On the liability side, open capital accounts in GCC countries lead to some competition. When the U.S. monetary policy tightens, and GCC central banks raise policy rates, domestic banks that do not follow by raising their own liability rates face increased competition from banks abroad. On the asset side, our results suggest that larger margins allow banks scope to absorb the impact of changes in monetary policy. This also implies that the effectiveness of monetary policy in terms of driving interest rates on loans is limited. From a policy perspective, measures to enhance competition focused on loan markets may assist with enhancing the transmission of monetary policy.

The remainder of this paper is structured as follows. Section II provides a brief discussion of related literature. Section III presents stylized facts based on the interest rate series we construct. Section IV lays out our conceptual framework and discusses our empirical findings.

Figure 1. GCC-Wide Bank and Policy Rates and U.S. Federal Funds Rate (Percent)

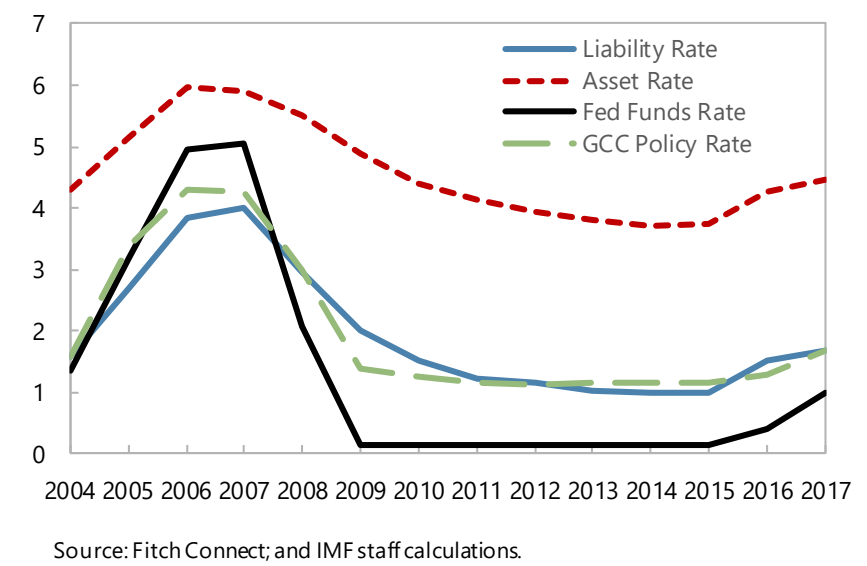

Section V concludes.

\section{STYlized FACTS}

We expect that monetary policy rates in GCC countries would tend to move in line with the federal funds rate given the pegged exchange rate regimes. In addition, in order for the monetary policy to be effective in terms of achieving desired objectives, the liability and asset rates would tend to be correlated with the GCC policy rates. In line with our expectation, GCC policy rates 
largely follow U.S. policy rates (Figure 1). ${ }^{3}$ Also, GCC bank assets rates have broadly followed the policy rates in their home countries (Figure 1). ${ }^{4}$ Appendix II, Figure 1 shows the evolution of these interest rates at the country level.

GCC banks' liability rates only partially responded to the increase in the U.S. Federal Funds rate during 2004-06 due to several factors. First, during this period, oil prices were relatively higher, with positive implications for banks' liquidity (see IMF (2017) and Adedeji and others (2019)). ${ }^{5}$ Second, banks may effectively have more market power when policy rates are high (Drechsler and others 2017). When policy rates are low, there is little room for banks to lower deposit rates - further reductions might lead depositors to switch to cash. In contrast, when policy rates are high, even at deposit rates well below policy rates, depositors are unlikely to switch to cash. Banks may therefore be able to set deposit rates well below policy rates at times when policy rates are high.

At the country level, policy rates are strongly positively correlated with the U.S. Federal Funds Rate (Table 1). Liability and asset rates also move with U.S. policy rates, although this comovement is stronger on the liability side (other than in Saudi Arabia).

\section{Table 1. Correlation of Policy and Bank Rates with U.S. Monetary Policy (2004-2017)}

\begin{tabular}{|l|c|c|c|c|c|}
\hline Country & $\begin{array}{c}\boldsymbol{\Delta} \text { Policy } \\
\text { Rate }\end{array}$ & $\begin{array}{c}\boldsymbol{\Delta} \text { Liability } \\
\text { Rate }\end{array}$ & $\begin{array}{c}\boldsymbol{\Delta} \text { Deposit } \\
\text { Rate }\end{array}$ & $\begin{array}{c}\boldsymbol{\Delta} \text { Asset } \\
\text { Rate }\end{array}$ & $\begin{array}{c}\boldsymbol{\Delta} \text { Loan } \\
\text { Rate }\end{array}$ \\
\hline Bahrain & 0.995 & 0.920 & 0.846 & 0.554 & 0.471 \\
Kuwait & 0.829 & 0.885 & 0.774 & 0.624 & 0.527 \\
Oman & 0.954 & 0.784 & 0.656 & 0.295 & 0.617 \\
Qatar & 0.922 & 0.678 & 0.042 & 0.501 & 0.246 \\
Saudi & 0.991 & 0.844 & 0.611 & 0.851 & 0.824 \\
UAE & 0.988 & 0.736 & 0.623 & 0.506 & 0.277 \\
\hline
\end{tabular}

Sources: Fitch Connect; Haver; and IMF staff calculations

Note: Each column shows correlation of a GCC interest rate with US Federal Funds Rate, at the country level, in changes.

\footnotetext{
${ }^{3}$ The policy rate refers to the one-week central bank deposit rate in Bahrain, the central bank discount rate in Kuwait, the average repo rate in Oman, the central bank deposit rate in Qatar, the reverse repo rate in Saudi Arabia (the reason for not using repo rate is that repo rate has been flat during the most recent U.S. tightening cycle), and central bank CD rate in the UAE. See Appendix I for more detail on definitions of key variables and a summary of data sources. We obtain these rates starting in 2003 for Kuwait, Qatar, and Saudi Arabia, 2004 for Bahrain and Oman, and 2007 for the UAE.

${ }^{4}$ The liability rate is defined as total interest expense divided by interest-bearing liabilities. A subset of this is the deposit rate, which is calculated as the interest expense on customer deposits divided by total customer deposits. The asset rate is gross interest and dividend income divided by interest-earning assets. The loan rate is a component of the asset rate and is calculated as interest income on loans divided by net loans. As Appendix I explains, Islamic compensation is included in the calculations of these interest rates.

5"Liquidity" is defined as the subset of central bank domestic currency liabilities vis-à-vis commercial banks that is readily avilable for payments purposes, essentially commercial bank excess reserves at the central bank (see Gray (2008) for a more-detailed discussion).
} 


\section{EMPIRICAL ANALYSIS}

\section{A. Panel Analysis Based on Time Series Variation}

We begin with bank level regressions where the dependent variables are changes in liability and asset rates and the independent variable is the change in the U.S. Federal Funds Rate (Table 2). All variables are expressed in percentage points. Specifications including either country or bank fixed effects are shown. In these and subsequent panel regressions, t-statistics are shown in parentheses, and are based on standard errors clustered by both country and year. ${ }^{6}$

Taken at face value, Table 2 suggests pass through from U.S. interest rates to GCC banks' liability and asset rates. The regressions suggest that when U.S. rates rise by 100 basis points, GCC banks' liability rates rise by 35 basis points and their asset rates by close to 20 basis points. We also find similar results using changes in country-specific policy rates as the independent variable instead.

However, as with any analysis based on country level data, it is difficult in these regressions to isolate the effect of changes in policy rates from other changes to the macroeconomic environment. Although they are based on bank level data, these regressions do not allow us to account for other important factors such as shocks to oil prices, changes in liquidity conditions, or global financial market developments.

\begin{tabular}{|c|c|c|c|c|}
\hline & $\Delta$ Liability Rate & $\Delta$ Liability Rate & $\Delta$ Asset Rate & $\Delta$ Asset Rate \\
\hline \multirow[t]{2}{*}{$\Delta$ Federal Funds Rate } & 0.35 & 0.35 & 0.19 & 0.18 \\
\hline & (7.51) & $(7.33)$ & (2.41) & (2.41) \\
\hline Country FE & $Y$ & $\mathrm{~N}$ & $\mathrm{Y}$ & $\mathrm{N}$ \\
\hline Bank FE & N & Y & N & Y \\
\hline Clustering & Country, Year & Country, Year & Country, Year & Country, Year \\
\hline R2 & 0.45 & 0.49 & 0.11 & 0.16 \\
\hline$N$ & 604 & 603 & 604 & 603 \\
\hline
\end{tabular}

\footnotetext{
${ }^{6}$ By double clustering standard errors, we adjust for correlation in errors both across years within country and across countries within year: these are the dimensions across which errors are most likely to be correlated.
} 
Our approach to address this issue is to shift our attention to cross-sectional variation and include year fixed effects in our regressions. Year fixed effects absorb all changes common to the region and provide a robust way to account for developments other than changes in interest rates. However, these cannot be included in the regressions presented in Table 2 as these only use variation in the time series - variation fully absorbed by year fixed effects. To use this approach, we focus on differences across banks in sensitivity to changes in U.S. monetary policy.

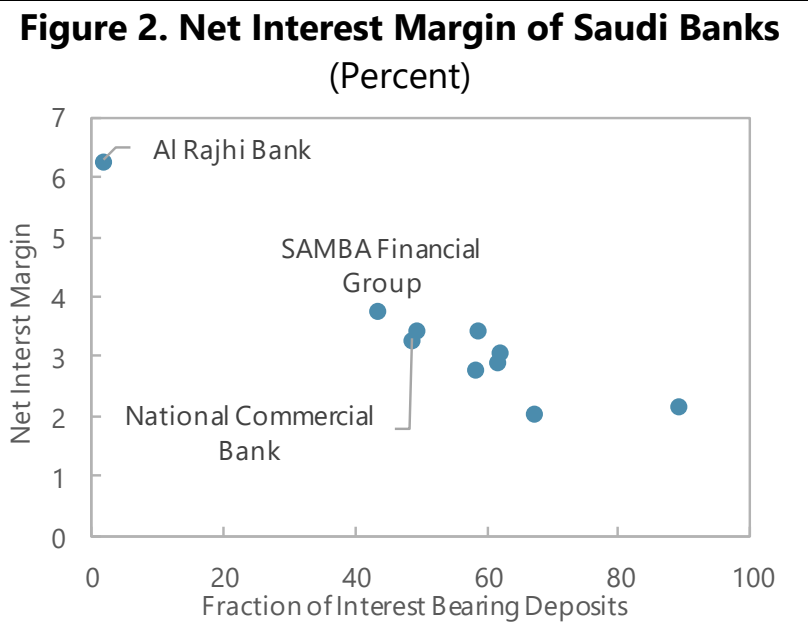

Sources: Fitch Connect and IMF staff calculations.

\section{B. Liability Pass-Through as Measure of Cross-Sectional Variation in Liability Interest-Sensitivity}

One important source of differential sensitivity to monetary policy across GCC banks is the deposit mix and the sensitivity of deposit interest rates. Figure 2 shows that the deposit mix can vary substantially across banks and seems to be associated with differences in net interest margins. Figure 2 shows that there is wide variation in the fraction of deposits that are interest bearing (as Appendix I notes, our data accounts for Islamic banking activity). Some banks have almost no deposits on which any form of compensation is paid, while others almost exclusively rely on compensated deposits. In Saudi Arabia, many of the most profitable banks (i.e. those with large Net Interest Margins) are able to fund themselves largely with deposits that are not compensated.

However, restricting attention to variation in the deposit mix may not be sufficient as nondeposit liabilities also play an important role in some GCC countries. Figure 3 shows that, although deposits dominate Saudi banks' liability structures, non-deposit liabilities such as wholesale funding are important for banks in Kuwait and Bahrain. This makes it important to capture the sensitivity of all bank liabilities, not just deposits, to changing interest rates.

We therefore construct a measure of the overall sensitivity of bank liabilities to changes in U.S. monetary policy at the bank level: liability pass-through (LPT). We estimate LPT using bank level regressions in which the dependent variable is the change in the bank's liability rate, and the independent variable is the change in the U.S. Federal Funds Rate: 
$\Delta$ Liability Rate $_{\mathrm{i}, \mathrm{t}}$

$$
\begin{aligned}
& =\alpha_{0} \\
& +\alpha_{1} \Delta \text { Federal Funds Rate } \\
& +\varepsilon_{\mathrm{i}, \mathrm{t}}
\end{aligned}
$$

The estimated coefficient $\hat{\alpha}_{1}$ is a measure of how sensitive a bank is to U.S. monetary shocks. For banks with $\hat{\alpha}_{1}$ close to 1 , liability rates respond almost one to one with U.S. monetary policy (sensitive banks), while for banks with $\hat{\alpha}_{1}$ close to 0 , liability rates do not respond strongly to U.S. monetary policy (insensitive banks). We use LPT as our main measure of cross-sectional variation across banks.

LPT is likely to link closely with the interest-bearing fraction of deposits in countries where deposits dominate, but may differ from the interest-bearing fraction of deposits in other countries. As discussed above, in some countries such as Kuwait and Bahrain, sources of funding other than deposits are important. Figure 4 shows that for the case of Saudi Arabia, where deposits dominate banks' liability structures, LPT is closely related to the interest-bearing fraction of deposits. Across GCC countries, while LPT is broadly in line with the interestbearing fraction of deposits for many banks, there are banks for which these two measures are very different (Figure 5).
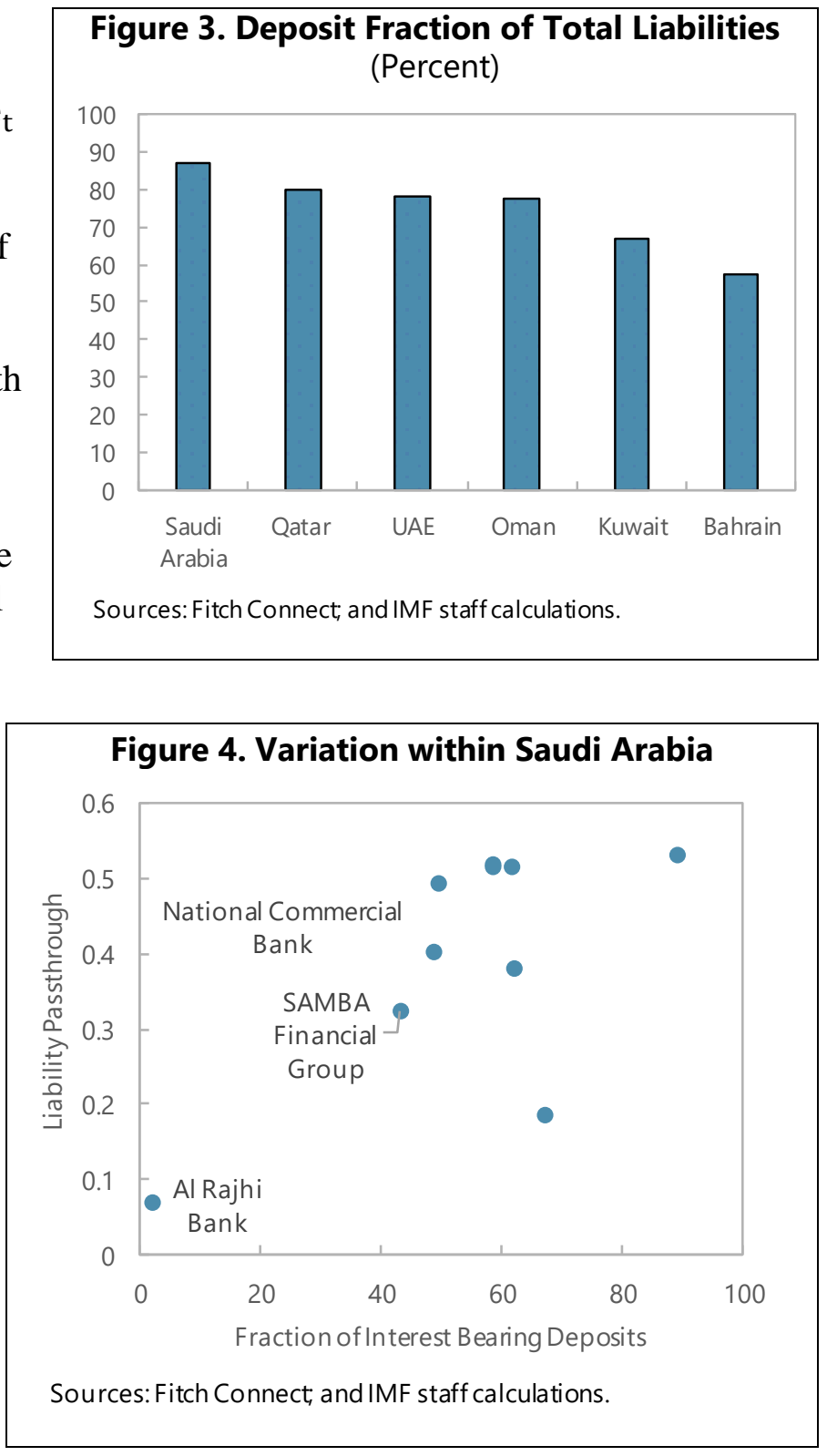

Figure 5 shows that while interest-bearing deposits are important for most GCC banks, some banks have essentially no interest-bearing deposits. Within banks that do have a substantial fraction of interest-bearing deposits, banks with similar fractions of interest-bearing deposits can have different LPTs for several reasons. Deposits may account for different fractions of liabilities. The strength of deposit franchises or market power may vary too. Within banks that have essentially no interest-bearing deposits, there are several distinct types of banks. Some have high LPT: these are primarily banks that rely on wholesale funding that must be obtained at 
market rates. ${ }^{7}$ Others have low LPT: these are banks that are able to fund themselves with uncompensated deposits, as is the case for some Saudi banks.

Overall, considering the sensitivity of all liabilities, and not just the sensitivity of deposits, is important. Our LPT approach better captures the overall sensitivity of bank liabilities to interest rates than measures based on the shares of different types of liabilities, as interestbearing deposits and wholesale liabilities can have different sensitivities to policy rates across banks and countries.

\section{Panel Analysis Based on Cross- Sectional Variation}

We now use differences in liability passthrough (LPT) as a source of differential sensitivity to changes in U.S. monetary policy. This allows us to present panel regressions similar to those presented in Table 2 that exploit cross-sectional variation and can include year fixed

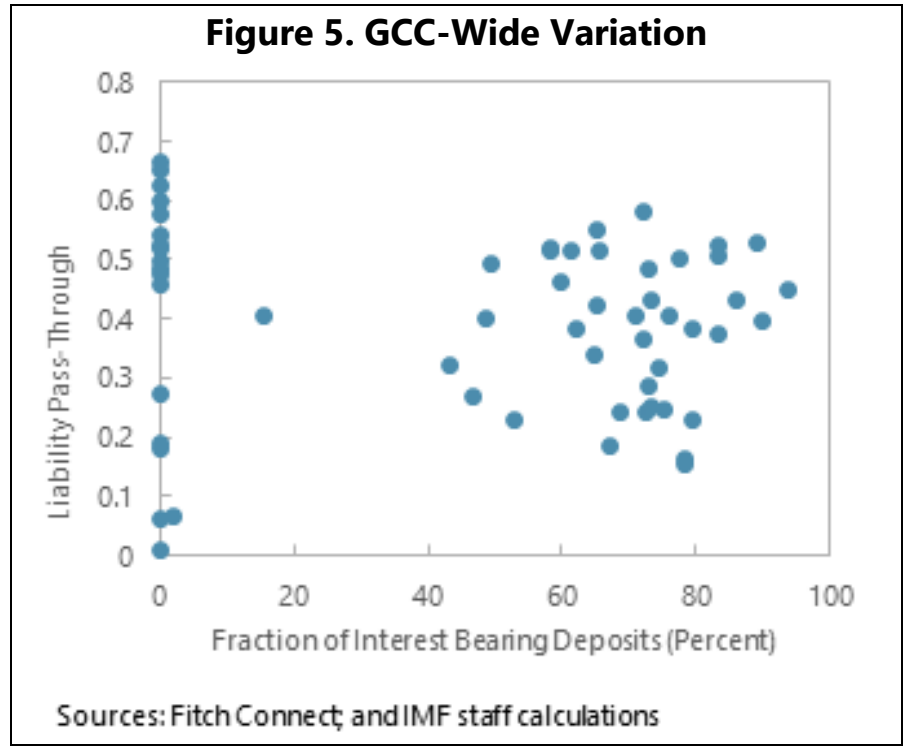
effects to control for macroeconomic developments other than changes in U.S. monetary policy. We ask whether banks with more sensitive liabilities also exhibit more sensitivity of assets and profitability. ${ }^{8}$ Kirti (2017) argues that the liability structure of U.S. banks is an important determinant of their asset structure in aggregate and presents evidence that banks with more interest-sensitive liabilities also choose to hold more interest-sensitive assets.

Table 4 presents panel regressions using this cross-sectional variation. The specification is:

$$
\Delta \text { Interest Rate }_{i, t}=\alpha_{\mathrm{t}}+\alpha_{i}+\alpha_{1} \Delta \text { Federal Funds Rate }_{t} \mathrm{x} \text { Liability Passthrough }{ }_{i}+\varepsilon_{i, t}
$$

The dependent variables are changes in interest rates or profitability at the bank level. These regressions include both year fixed effects $\left(\alpha_{\mathrm{t}}\right)$ and bank fixed effects $\left(\alpha_{i}\right)$. The coefficient of interest is $\alpha_{1}$ : the interaction between changes in the U.S. Federal Funds Rate and LPT. This coefficient looks at the differential impact of changes in U.S. monetary policy on banks with more sensitive liabilities. Year and bank fixed effects absorb the individual variables. As in Table 2, $\mathrm{t}$-statistics are shown in parentheses, with standard errors double clustered by country

\footnotetext{
${ }^{7}$ There are also some banks for which the interest-bearing fraction of deposits is low, deposits are a significant share of liabilities, and LPT is high. These may be banks for which the interest-bearing fraction of deposits is not reported correctly.

${ }^{8}$ Our focus is on the effect of U.S. monetary policy shocks on GCC banks. While GCC policy rates are highly correlated with U.S. monetary policy, it is also possible that changes in U.S. monetary policy directly affect GCC banks, for example by changing the ease with which dollar funding can be accessed. Our measure of liability sensitivity captures both channels.
} 
and year. As U.S. monetary policy is not set to target financial conditions in GCC countries, this approach captures differences in GCC banks' exposures to exogenous shocks.

\begin{tabular}{|c|c|c|c|}
\hline & $\Delta$ Liability Rate & $\Delta$ Asset Rate & $\Delta$ Net Interest Margin \\
\hline \multirow[t]{2}{*}{$\begin{array}{l}\text { Federal Funds Rate } x \text { Liability } \\
\text { Passthrough }\end{array}$} & 0.74 & 0.47 & -0.11 \\
\hline & (3.34) & (1.3) & $(-1.02)$ \\
\hline Country FE & $N$ & $\mathrm{~N}$ & $\mathrm{~N}$ \\
\hline Year FE & $Y$ & $Y$ & $Y$ \\
\hline Bank FE & $Y$ & $Y$ & $Y$ \\
\hline Clustering & Country, Year & Country, Year & Country, Year \\
\hline R2 & 0.66 & 0.31 & 0.18 \\
\hline $\mathrm{N}$ & 603 & 603 & 603 \\
\hline
\end{tabular}

The results in Table 3 show that while there is substantial variation in the impact of U.S. monetary policy on GCC banks' liability rates, there seems to be little systematic differential impact on asset rates or profitability. On the liability side, as expected, liability rates respond substantially more to shifting U.S. monetary policy for banks with higher LPT. Relative to a bank with no liability pass-through, if the U.S. Federal Funds Rate rises by 100 basis points, liability rates rise by an additional 74 basis points for a bank with one-to-one liability passthrough. Focusing on the estimated sign and magnitude of the coefficient for asset rates, banks with higher LPT do seem to raise asset rates more when U.S. rates rise, although not as much as they raise their liability rates. Correspondingly, the estimated differential impact on profitability is negative. However, the latter two coefficients cannot be statistically distinguished from zero. In the cross section of GCC countries, therefore, some GCC banks are more sensitive on the liability side, but we are unable to detect a robust differential effect on asset rates or on profitability at the GCC level.

\section{Availability of Funding and Bank Competition}

We explore two potential factors that may help explain why we do not find a systematic effect of U.S. monetary policy on asset rates and profitability in the cross section. First, we consider changes in the quantity and structure of banks' funding. Shifting quantities may explain why prices do not respond as much as expected. We find some evidence to support this interpretation. Second, we examine the role of differences in bank competition across countries.

We begin by studying whether shifting U.S. monetary policy differentially affects the quantity and structure of banks' liabilities for sensitive banks. Banks with high LPT raise liability rates more for a given increase in U.S. policy rates. Our analysis so far has abstracted from how the quantity of liabilities responds to this change in prices. Perhaps more sensitive banks attract relatively more funding when U.S. rates rise, given that they offer more attractive deposit rates. 


\begin{tabular}{|lcc|}
\hline \multicolumn{3}{|c|}{ Table 4. Response of Quantities to Changes in U.S. Monetary Policy } \\
\hline & $\boldsymbol{\Delta}$ In (Liabilities) $\mathbf{~ 1 0 0}$ & $\boldsymbol{\Delta} \mathbf{l n}$ (Assets) $\mathbf{~ 1 0 0 ~}$ \\
\hline$\Delta$ Federal Funds Rate x Liability Passthrough & 7.52 & 6.6 \\
& $(1.91)$ & $(1.64)$ \\
\hline Country FE & $\mathrm{N}$ & $\mathrm{N}$ \\
Year FE & $\mathrm{Y}$ & $\mathrm{Y}$ \\
Bank FE & $\mathrm{Y}$ & $\mathrm{Y}$ \\
Clustering & Country, Year & Country, Year \\
R2 & 0.57 & 0.59 \\
$\mathrm{~N}$ & 603 & 603 \\
\hline Sources: Fitch Connect; and IMF staff calculations. & & \\
\hline
\end{tabular}

Regressions where dependent variables are changes in the overall size of liabilities and assets, presented in Table 4, suggest that more sensitive banks may attract more funding when U.S. rates rise. The dependent variables here are log-changes, multiplied by 100 , so that coefficients can be interpreted as changes in quantities in percentage points. Relative to a bank with no liability sensitivity, a bank with one-to-one liability pass-through sees an additional 7.5 percentage points of overall liability growth for a 100 basis point increase in U.S. rates. Its assets correspondingly grow by close to an additional 7 percentage points as well, although the coefficient is not statistically significantly different from zero. It seems plausible that this additional inflow of funding can help explain why the differential impact of U.S. monetary policy on sensitive banks' asset rates is limited. As sensitive banks need to substantially grow their assets when U.S. rates rise, they may find it difficult to simultaneously increase asset rates by as much.

If more sensitive banks' higher liability rates attract more funding when U.S. rates rise, this new funding should arrive in the form of compensated deposits. Non-deposit funding is likely obtained at market rates in any case, while uncompensated deposits are relatively less attractive when interest rates are high. Table 5 shows that sensitive banks' new liabilities are indeed in the form of compensated deposits. Relative to a bank with no liability sensitivity, compensated deposits grow by close to 7 percentage points for a bank with one-to-one liability pass-through for a 100 basis point increase in U.S. rates, while uncompensated deposits actually shrink. We find little effect on liabilities other than deposits. In the absence of the ability to effectively price discriminate, this approach allows sensitive banks to retain their existing base of funding, even if it does reduce profitability per unit of assets held.

Our findings suggest that GCC banks' depositors respond to price incentives. When U.S. interest rates rise, liability sensitive banks raise their liability rates substantially more than banks that are not sensitive (Table 3). Our results in Tables 4 and 5 show that depositors at sensitive banks respond by increasing holdings of compensated deposits and reducing their holdings of uncompensated deposits. Again, our methodology compares sensitive banks to less sensitive banks. Our findings suggest that even in GCC countries, where Islamic banking plays an important role, and some banks are able to fund themselves almost entirely with uncompensated 
deposits (Figure 2), depositors do respond to relative prices. Banks that follow rising U.S. rates by offering higher deposit rates attract relatively more compensated deposits.

\begin{tabular}{|c|c|c|c|}
\hline \multicolumn{4}{|c|}{ Table 5. Response of Liabilities to Changes in U.S. Monetary Policy } \\
\hline & $\begin{array}{c}\Delta \ln \text { (Interest Bearing } \\
\text { Deposits) }\end{array}$ & $\begin{array}{c}\Delta \ln \text { (Non Interest Bearing } \\
\text { Deposits) }\end{array}$ & $\begin{array}{c}\Delta \ln \text { (Other } \\
\text { Liabilities) } \\
\end{array}$ \\
\hline \multirow[t]{2}{*}{$\Delta$ Federal Funds Rate $x$ Liability Passthrough } & 6.78 & -8.47 & 2.1 \\
\hline & $(3.55)$ & $(-2.31)$ & $(0.19)$ \\
\hline Country FE & $\mathrm{N}$ & $\mathrm{N}$ & $\mathrm{N}$ \\
\hline Year FE & Y & Y & $\mathrm{Y}$ \\
\hline Bank FE & Y & Y & Y \\
\hline Clustering & Country, Year & Country, Year & Country, Year \\
\hline R2 & 0.2 & 0.16 & 0.24 \\
\hline $\mathrm{N}$ & 484 & 595 & 603 \\
\hline
\end{tabular}

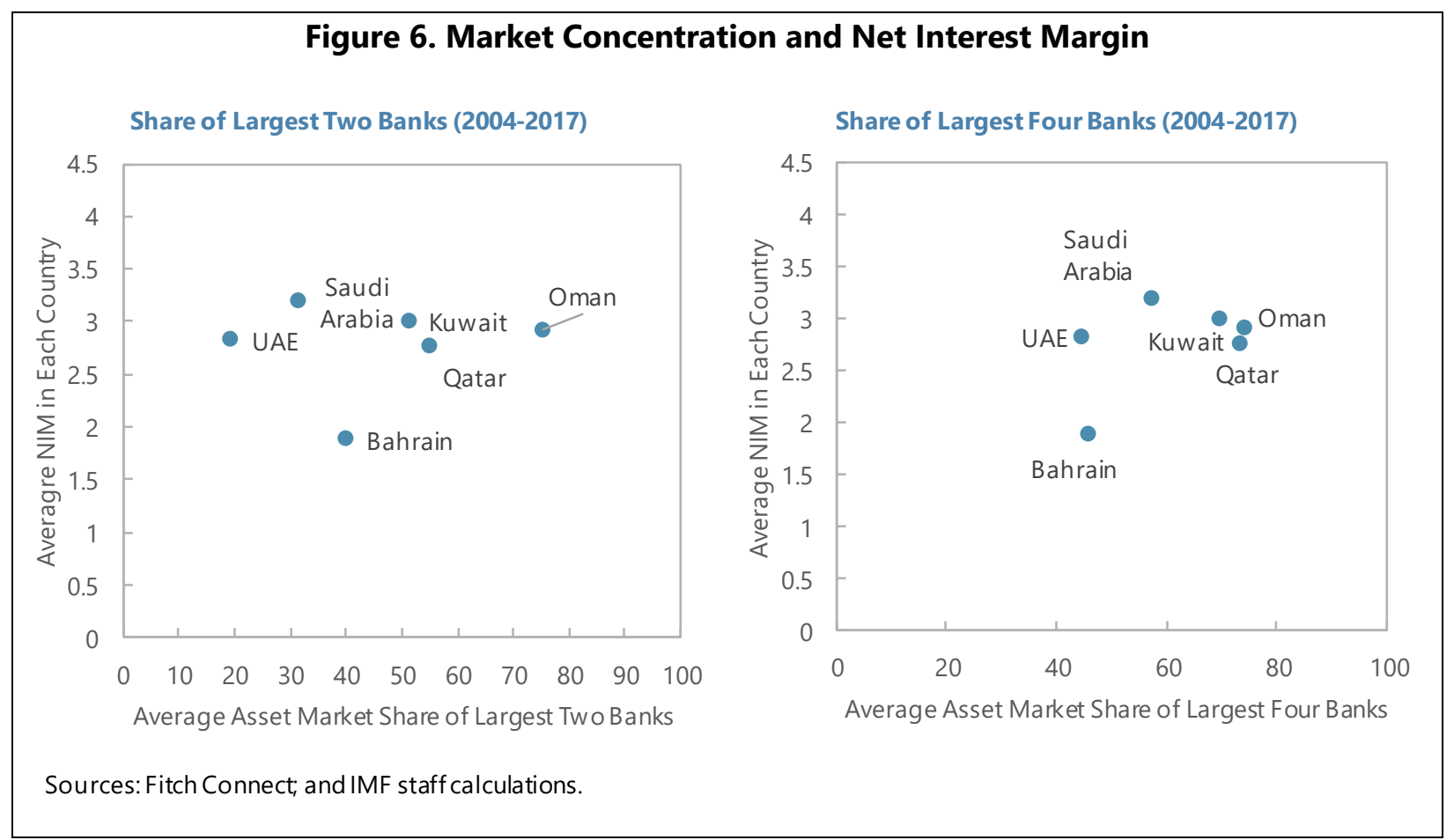

Next, we examine the role of bank concentration. Figure 6 shows concentration of the banking systems in GCC countries based on the market share of the largest two and the largest four banks. GCC banking systems are concentrated: the top four banks account for more than 40 percent of assets in the UAE and Bahrain, about 60 percent of assets in Saudi Arabia, and about 70 percent of assets in Kuwait, Qatar, and Oman. Larger banks are more likely to be banks with market power: indeed, in four of the six countries we find a negative correlation between bank size and interest-rate pass-through to deposits. 
We find suggestive evidence that differences in bank concentration can help explain our finding that U.S. rates have a limited impact on profitability in the cross section. Figure 7 shows how the impact of U.S. rates on profitability varies with bank concentration. The vertical axis is the coefficient from country level versions of the third specification shown in Table 3. More negative coefficients imply a greater negative impact on profitability of rising U.S. rates for more sensitive banks. The horizontal axis of this figure is the Herfindahl-Hirschman Index (HHI), a continuous measure of concentration that ranges from $0-10000 .{ }^{9}$ A larger $\mathrm{HHI}$ indicates more concentration. Rising U.S. rates seem to matter more for sensitive banks' profitability in GCC countries with more concentrated banking systems. For three countries we find a statistically significant negative impact of rising U.S. rates on sensitive banks' profitability (Bahrain, Oman, and Qatar, shown in Figure 7 in bold). Of these, Oman and Qatar have relatively concentrated banking systems by all three measures of concentration (the market share of the largest two and largest four banks, and the HHI).

Rising U.S. rates may impair profitability for sensitive banks in more concentrated banking systems if sensitive banks in these systems have to raise liability rates more for a given increase in U.S. rates. Particularly if more liability sensitive banks are not themselves the dominant banks (as we find is the case in four of the six GCC countries), they may find it necessary to raise deposit rates to retain their deposit base when U.S. rates rise, but may not be able to increase their asset rates to match this increase in their cost of funding. Table 6 examines whether this is the case, but statistical power is limited here, as our sample only covers six countries, and the results are not statistically significant.

\footnotetext{
${ }^{9}$ The HHI is calculated as the sum of individual market participants' market shares squared. For example, a monopolist has a 100 percent market share, and the HHI is therefore a maximal 10000.
} 


\begin{tabular}{|c|c|c|}
\hline \multicolumn{3}{|c|}{ Table 6. Regressions Using Variation in Competition } \\
\hline & $\Delta$ Liability Rate & $\Delta$ Liability Rate \\
\hline \multirow[t]{2}{*}{ Liability Passthrough } & -0.54 & \\
\hline & $(-1.65)$ & \\
\hline \multirow[t]{2}{*}{$\triangle$ FFR $x$ Liability Passthrough } & 0.29 & 0.34 \\
\hline & $(0.85)$ & $(0.95)$ \\
\hline \multirow[t]{2}{*}{$\Delta \mathrm{FFR} \times \mathrm{HHI}$} & -0.75 & -0.55 \\
\hline & $(-1.14)$ & $(-0.81)$ \\
\hline \multirow[t]{2}{*}{ Liability Passthrough x HHI } & 3.13 & \\
\hline & $(1.70)$ & \\
\hline \multirow[t]{2}{*}{$\triangle$ FFR $\times$ Liability Passthrough $\times \mathrm{HHI}$} & 2.84 & 2.39 \\
\hline & $(1.61)$ & $(1.3)$ \\
\hline Country FE & $\mathrm{Y}$ & $\mathrm{N}$ \\
\hline Year FE & Y & Y \\
\hline Bank FE & $\mathrm{N}$ & Y \\
\hline Clustering & Country, Year & Country, Year \\
\hline $\mathrm{R} 2$ & 0.64 & 0.67 \\
\hline$N$ & 604 & 603 \\
\hline
\end{tabular}

\section{Conclusion}

In this paper, we use bank-level data to explore the effect of changes in the U.S. federal funds rate on banks in the GCC countries. We find stronger pass-through from U.S. to GCC policy rates and bank liability rates than to asset rates and bank profitability. The joint evolution of prices and quantities may help explain the limited sensitivity of asset rates: banks that must raise liability rates to match a tightening of U.S. monetary policy tend to attract additional funding which they then need to lend out, leaving little scope for raising asset rates. The presence of large banks with relatively insensitive liabilities also constrains more sensitive banks' ability to raise rates.

From a policy perspective, there may be room to improve monetary policy transmission to loan rates. Measures to enhance competition with emphasis on the loan market could help enhance the transmission of monetary policy. 


\section{APPENDIX I. DATA}

We use annual bank-level data from Fitch Connect. Our sample period is 2004-2017. For consistency, we exclude banks for which coverage begins after 2004. Table 1 shows the number of banks included in the sample for each country.

\begin{tabular}{|l|r|}
\hline \multicolumn{2}{|c|}{ Table 1. Sample Size } \\
\begin{tabular}{|l|r|}
\hline Country & No. of Banks \\
\hline Bahrain & 20 \\
\hline Kuwait & 16 \\
\hline Oman & 8 \\
\hline Qatar & 8 \\
\hline Saudi Arabia & 11 \\
\hline United Arab Emirates (UAE) & 20 \\
\hline
\end{tabular}
\end{tabular}

We obtain data on policy rates for Bahrain (one-week deposit rate), Kuwait (central bank discount rate), Oman (repo rate), Qatar (deposit rate), Saudi Arabia (reverse repo rate), United Arab Emirates (central bank CD rate) and the United States (Federal Funds rate) from Haver.

Bank-level implied interest rates are calculated as follows:

- Liability side: The liability rate is interest expense scaled by interest-bearing liabilities. The deposit rate is interest expense on customer deposits scaled by customer deposits.

- Asset side: The asset rate is gross interest and dividend income scaled by interestearning assets. The loan rate is calculated as interest income on loans divided by net loans.

- Profitability: We focus on the net interest margin (NIM)-net interest income scaled by total interest-earning assets.

We also calculate these rates at the country and GCC levels as bank size-weighted averages (we calculate implied interest rates treating the relevant group of banks as a single bank).

The data covers Islamic banking. Taking the example of Saudi Arabia, banks' financial statements report all sources of income, including 'special commission' compensation on assets and liabilities associated with Islamic banking operations. Fitch classifies these receipts and payments as interest income and interest expense. 


\section{APPENDix II. AdDitional Figures}

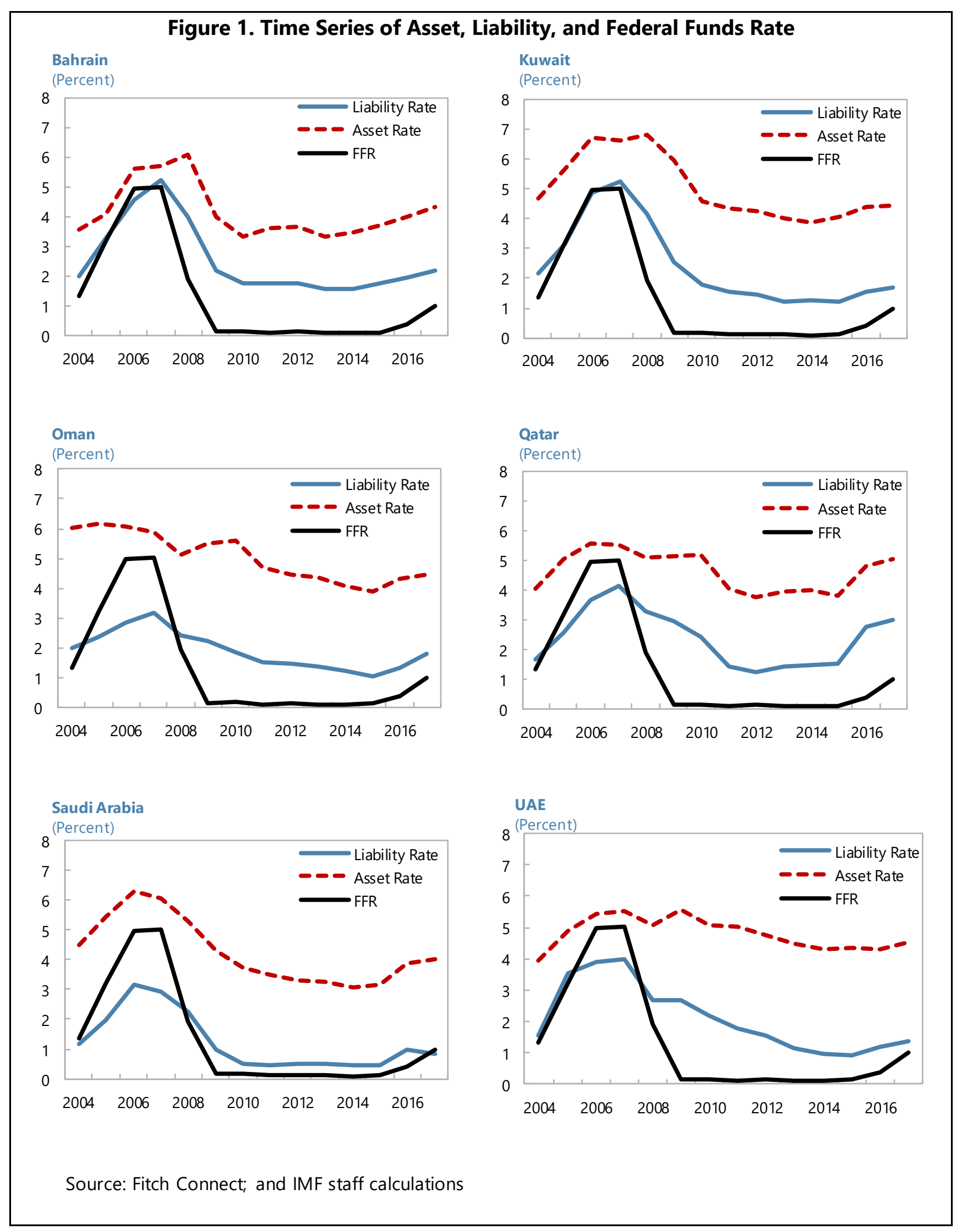




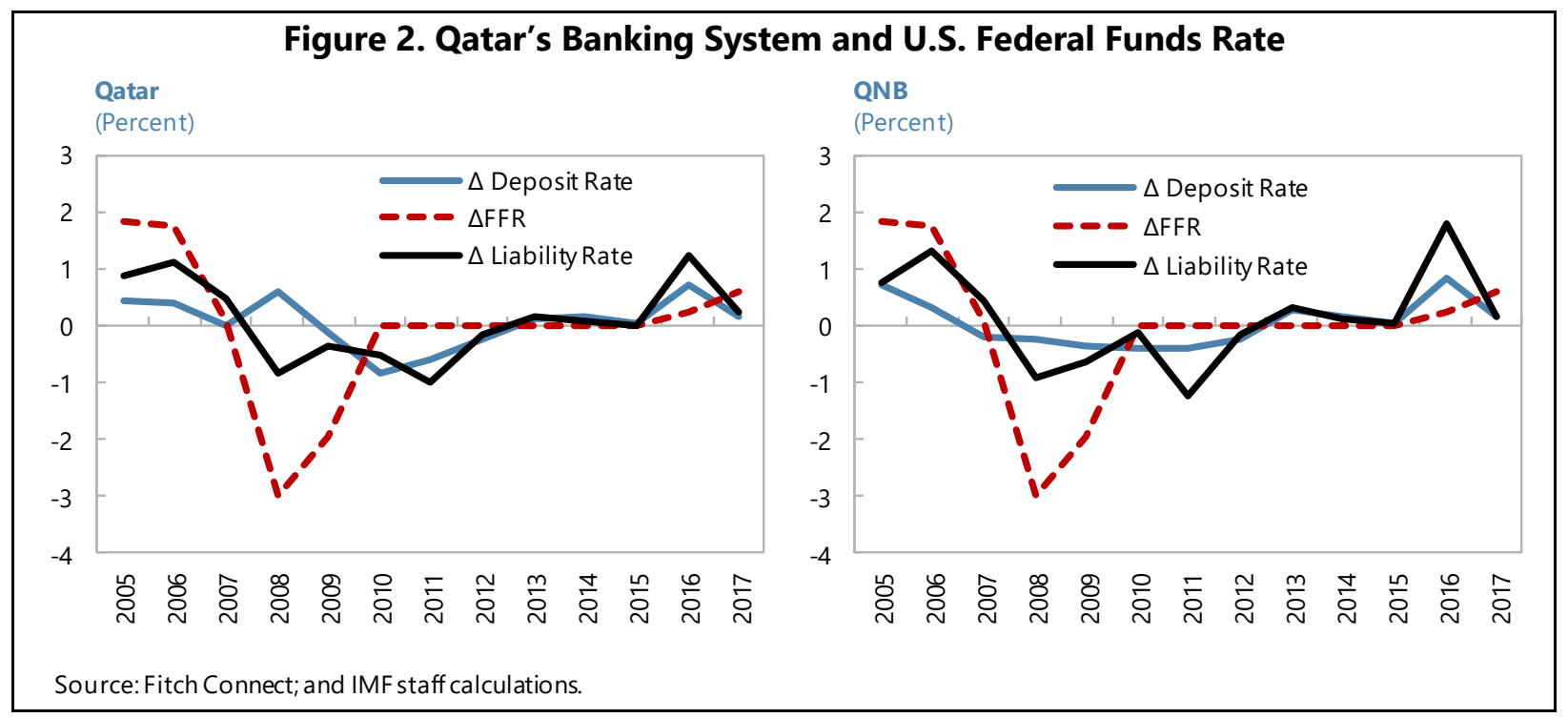




\section{REFERENCES}

Adedeji, O., Shahid, S. and Zhu, L.: U.S. Monetary Policy and Spillovers in GCC (2018): An Empirical Analysis. International Monetary Fund.

Alessandri, P., and Nelson, B.D (2015). Simple Banking: Profitability and the Yield Curve. Journal of Money, Credit and Banking, 47(1):143-175.

Alghaith, N., A. Al-Darwish, P. Deb, and P. Khandelwal, (2014), " Monetary and Macroprudential Policies in Saudi Arabia" in Saudi Arabia: Tackling Emerging Economic Challenges to Sustain Growth, IMF.

Drechsler, I., Savov, A. and Schnabl, P., (2017). The deposits channel of monetary policy. Quarterly Journal of Economics.

English, W. B. (2002). Interest rate risk and bank net interest margins. BIS Quarterly Review, December, 67-82.

Espinoza, R. and Prasad, A. (2012). Monetary Policy Transmission in the GCC Countries. International Monetary Fund.

Gray, Simon, "Liquidity Forecasting.” Handbook No.27. Centre for Central Banking Studies, Bank of England.

IMF, (2019). Saudi Arabia 2019 Article IV Consultation. IMF Country Report No. 19/290. International Monetary Fund.

Khandelwal, P., Miyajima, M. K., and Santos, A. (2016). The impact of oil prices on the banking system in the GCC. IMF Working paper 16/161. International Monetary Fund.

Kirti, D., (2017). Why do bank-dependent firms bear interest-rate risk? International Monetary Fund.

Van Leuvensteijn, M., Sorensen, CK, Bikker, J, and van Rixtel, A (2013). Impact of bank competition on the interest rate pass-through in the euro area. Applied Economics.

Sheehan, R. and Russer, J, (1995), “A Vector Autoregressive Model of the Saudi Arabian Economy," Journal of Economics and Business, 90. 